\title{
Illustrating Adverse Selection in Health Insurance Markets with a Classroom Game
}

\author{
Jennifer M. Mellor \\ College of William and Mary
}

College of William and Mary

Department of Economics

Working Paper Number 11

December 2004

Revised March 2004

The author is grateful to students in several classes who participated in versions of this experiment and to Lisa Anderson for giving helpful feedback and for allowing her to run the experiment in her class. 
COLLEGE OF WILLIAM AND MARY

DEPARTMENT OF ECONOMICS

WORKING PAPER \# 11

December 2004, Revised March 2004

\title{
Illustrating Adverse Selection in Health Insurance Markets with a Classroom Game
}

\begin{abstract}
This paper describes a classroom game that illustrates the effects of asymmetric information and adverse selection in health insurance markets. The first part of this game simulates a market in which buyers can purchase insurance from sellers; in some periods, government regulation of the insurance market prevents sellers from using information about buyer type to determine premiums. The results demonstrate the classic prediction that asymmetric information will result in adverse selection. Here, low risk buyers will forego the purchase of insurance at a measurable loss of potential earnings. In the second part of the game, sellers and buyers can trade two different types of health insurance policies, one moderate and another generous. The results from this part show that adverse selection can lead to an inefficient sorting of buyers across plans under government-mandated community rating and limits on premium increases. Under these circumstances, no buyers will purchase the generous insurance plan. The paper provides a series of questions to stimulate class discussion on the causes and consequences of adverse selection for consumers and insurers, and solutions that can be implemented in employer and governmentsponsored programs.
\end{abstract}

JEL Codes: A2, C9, D4, I1

Keywords: Classroom, Experiment, Adverse Selection

Jennifer Mellor

Department of Economics

College of William and Mary

P.O. Box 8795

Williamsburg, VA 23187-8795

jmmell@wm.edu 


\section{Introduction}

Theoretical lessons about common insurance market failures can be made accessible to students through the use of case studies, legislative proposals, and other evidence from the "real world." In this paper, I describe a classroom demonstration of a health insurance market in which asymmetric information leads to adverse selection under different insurance regulatory regimes. The basic set-up builds on the exercise used by Holt and Sherman (1999) to illustrate how asymmetric information about product quality can lead to adverse selection in the goods market. The first part of this game simulates a market in which low and high risk buyers can purchase insurance policies from sellers; in some periods, government-mandated community rating prevents sellers from using information about buyer type to determine premiums. The results demonstrate several textbook predictions regarding the effect of asymmetric information on insurance markets, namely that it can lead low risk buyers to drop out of the market, and that it can reduce consumer welfare.

The second part of the game adds a layer of complexity by allowing sellers and buyers to exchange two types of health insurance policies, one moderate and another generous. This feature reflects a common practice in many employer and government-sponsored insurance programs. Like the first, this part of the game also shows how adverse selection can lead low risk buyers to forego insurance under government-mandated community rating. In addition, a government regulation that limits premium increases demonstrates how adverse selection can lead to an inefficient sorting of buyers across plans, with none of the buyers selecting the 
generous plan. The results of either part of the game can be incorporated into classroom discussions of the causes and consequences of adverse selection for consumers and insurers, and solutions that employers and government payers can implement. The results from the second part of the game can be used to discuss the sequence of events leading to adverse selection "death spirals" (when generous plans are no longer offered in the market), and strategies to deter this type of adverse selection, such as retrospective risk adjustment and the use of proportional subsidies in employer-sponsored plans.

This game can be used to illustrate adverse selection in undergraduate courses such as health economics, and intermediate or advanced microeconomic theory. First-time users of the game may prefer to run each part in separate class periods followed by discussion. With practice, you can carry out both parts of the game in one 75-minute class and hold class discussion in a subsequent period, or you may continue running the parts separately if class periods are shorter. ${ }^{1}$ The exercises work with groups of 10 to 35 students, and require only a few index cards to be prepared in advance and copies of the instruction and record sheets included in the Appendix.

\section{Classroom Demonstration Procedures}

Begin by dividing the students evenly into seven different groups of roughly equal size. ${ }^{2}$ Three groups will act as sellers of insurance and four groups will act as buyers; it is helpful to have buyers and sellers sit in groups on separate sides of the room so that information is not

${ }^{1}$ With minor modifications to the first section of the Part 2 instructions, you can skip Part 1 and run Part 2 by itself. One downside to this is that without the "warm-up" exercise of Part 1, convergence to equilibrium prices in the full information periods of Part 2 may not happen as quickly.

2 If you have fewer than 14 students, individual students can play the role of buyers while pairs of students act as sellers, the slightly more intensive role. 
shared. In the description below, I use the term "seller" to refer to a group of students acting collectively as one seller and the term "buyer" to refer to a group acting as one buyer.

\section{Part 1: An Insurance Market with Two Types of Buyers and One Type of Policy}

Give each group member either a seller or buyer Part 1 instruction sheet and provide each group with a Part 1 record sheet according to their roles in the market. You can read aloud the common portions of the instructions, which are the "Introduction" and "Decisions" sections, pausing during the "Earnings" section for students to read this privately. The common portions inform the students about the basic structure of the game, and the types of decisions to be made by buyers and sellers in several periods of play; the private portion contains information about seller costs and buyer values which should not be revealed to the entire class.

\section{Full Information Periods}

In the first few periods, sellers and buyers both have information about the "type" of the buyer involved in the exchange. Note that buyer type is meant to correspond to risk level, but it is not necessary to make that connection to students. Similarly, the terms full and asymmetric information are used here to describe the structure of the game, but you can avoid using them during the game. Begin each period by instructing sellers to determine two premiums for an insurance policy which will be "sold" to buyers and to write these values on their record sheets. Specifically, sellers must determine a premium for a policy sold to a type 1 buyer, and a premium for a policy sold to a type 2 buyer; sellers do not choose the quantity produced. In making these decisions, sellers know from the instructions that their earnings are calculated as the difference between the premium received and the cost of the policy, and that sellers who do not sell a policy have earnings equal to zero. The seller instruction sheets also denote the costs of a policy sold to 
a type 1 buyer and a type 2 buyer. The cost of selling a policy to a type 2 buyer exceeds the cost of selling to a type 1 buyer, as shown in Table 1 below.

Table 1. Seller Cost and Buyer Value in Part 1

\begin{tabular}{|l|l|l|}
\hline & Type 1 Buyer & Type 2 Buyer \\
\hline Cost of policy to seller & $\$ 40$ & $\$ 70$ \\
\hline Value of policy to buyer & $\$ 50$ & $\$ 90$ \\
\hline
\end{tabular}

While sellers make decisions about their premiums, you should randomly assign buyer type by having one member of each buyer group draw one of four index cards. For this, you will need to have two cards that have been marked in advance as "Type 1" and two cards marked as “Type 2." As soon as all sellers are finished determining the two premiums, collect the seller record sheets and post this information in a table for all students to see. If you use the blackboard rather than a transparency, you may also want to keep a paper record of the decisions for subsequent analysis. Table 2 illustrates one method of reporting this information; note that in each period there will be a total of six values posted on the board (two premiums from each of three sellers). Then, return the record sheets to sellers.

Once premiums are displayed, give buyers the opportunity to purchase a policy. Buyers know from the instructions that their earnings are calculated as the difference between the value of the policy to the buyer and the premium paid for the policy. The value of an insurance policy to a type 2 buyer exceeds the value of insurance to a type 1 buyer, as shown in Table 1 . Any buyer can also elect not to purchase a policy; in this case, earnings for the buyer will equal zero. Ask each buyer, in turn, to reveal buyer type, to choose whether to purchase a policy or not, and finally, to state the seller from which the policy is purchased. Limit each seller to the sale of no 
more than two policies of any type or types. This will increase the number of students who can participate in the game and streamline seller calculations to fit the record sheet.

When all buyer and seller groups have recorded their earnings from the first period, repeat the process above several times. You should shuffle and redistribute the index cards denoting buyer type at the beginning of each new period. To further increase student interest, it is helpful to begin the purchasing in each period with a different buyer; you can start with buyer 1 in period 1 , buyer 2 in period 2, and so on, or you can draw cards to determine the order. After two or three additional periods, you should expect the premiums of policies sold to range from $\$ 40$ to $\$ 50$ for type 1 buyers, and $\$ 70$ to $\$ 90$ for type 2 buyers. If the market (i.e., the group of students acting as sellers) is competitive, policies will be sold at or very close to cost; that is, type 1 buyers will pay close to $\$ 40$ for a policy, and type 2 buyers will pay close to $\$ 70$. The results in Table 2 show that fourth period premiums were very close to the competitive level in this classroom exercise, at $\$ 41$ and $\$ 70.01$ for type 1 and 2 buyers respectively. Asymmetric Information Periods

After a period in which you observe selling premiums that are at or near the competitive level, announce that a change will be made. Specifically, you can read: "The state legislature has just enacted a community rating regulation, which requires insurance companies to set premiums at the same level for all buyers. Premiums set by sellers in this next period are subject to this new regulation, and no seller can refuse a sale at the posted premium in light of the buyer's type." This announcement introduces an insurance market regulation that has been adopted by many states to increase access to healthcare. By 2003, ten states had implemented mandatory community rating of some form in the individual insurance market and fifteen states 
had done so in the small group market (Kaiser Family Foundation, 2004). The last part of the announcement makes the change more effective by adding a restriction similar to federal law requiring "guaranteed issue" in the small group market under the Health Insurance Portability and Accountability Act (HIPAA) of 1996.

Table 2. Sample Results from Part 1, by Period

\begin{tabular}{|c|c|c|c|}
\hline Period & Seller A & Seller B & Seller C \\
\hline 1: Full & T1:\$49: Sold 2 & $\mathrm{~T} 1: \$ 50$ & $\mathrm{~T} 1: \$ 60$ \\
\hline Information & $\mathrm{T} 2: \$ 84$ & T2:\$80: $\underline{\text { Sold } 2}$ & $\mathrm{~T} 2: \$ 90$ \\
\hline 2: Full & $\mathrm{T} 1: \$ 46$ & T1:\$44: Sold 1 & $\mathrm{~T} 1: \$ 44: \underline{\text { Sold } 1}$ \\
\hline Information & T2:\$77: Sold 2 & $\mathrm{~T} 2: \$ 78$ & $\mathrm{~T} 2: \$ 78$ \\
\hline 3: Full & $\mathrm{T} 1: \$ 42: \underline{\text { Sold } 1}$ & $\mathrm{~T} 1: \$ 42: \underline{\text { Sold } 1}$ & $\mathrm{~T} 1: \$ 42$ \\
\hline Information & T2:\$73: $\underline{\text { Sold } 1}$ & T2:\$73: $\underline{\text { Sold } 1}$ & $\mathrm{~T} 2: \$ 74$ \\
\hline 4: Full & $\mathrm{T} 1: \$ 41: \underline{\text { Sold } 1}$ & T1:\$41: Sold 1 & $\mathrm{~T} 1: \$ 41$ \\
\hline Information & $\mathrm{T} 2: \$ 71$ & $\mathrm{~T} 2: \$ 71$ & T2:\$70.01: $\underline{\text { Sold } 2}$ \\
\hline $\begin{array}{l}\text { 5: Asymmetric } \\
\text { Information }\end{array}$ & $\begin{array}{l}\$ 64: \text { Sold } 2 \text { to Type } 2 \\
\text { buyers at a loss }\end{array}$ & $\$ 74$ & $\$ 71$ \\
\hline $\begin{array}{l}\text { 6: Asymmetric } \\
\text { Information }\end{array}$ & $\$ 70.50$ & $\$ 70.50$ & $\begin{array}{l}\$ 56: \text { Sold } 2 \text { to Type } 2 \\
\text { buyers at a loss }\end{array}$ \\
\hline
\end{tabular}

Notes: This table reports the classroom results from the author's Economics of Healthcare course, for the Spring 2003 semester. Each cell shows premiums requested by sellers in periods of the classroom game. In the full information periods, T1 and T2 designate premiums for Type 1 and Type 2 buyers respectively.

While sellers decide premiums, you should repeat the process of distributing the index cards randomly to buyers. Again post the premiums asked by sellers in public view, and ask each buyer, one at a time, to state whether or not the group chooses to purchase, and if so, from which seller. Buyers must also reveal their type so that sellers can calculate their earnings, and it is fun 
to ask the buyers to state this last, and watch a seller's enthusiasm about a sale turn to concern in some cases. If a seller's strategy given the lack of information about buyer type is to set the premium between the costs of insuring type 1 and type 2 buyers, and the seller subsequently makes a sale to a type 2 buyer, the seller will incur negative earnings. This result is shown in Table 2 for periods 5 and 6.

Once all sales are made for the first period under mandatory community rating, remind sellers and buyers to again calculate their earnings based on the premium and the cost or value associated with the specific buyer type. The process can be repeated for a few additional periods. Sellers should quickly learn that premiums should be greater than or equal to the cost of insuring the type 2 buyer in order to prevent a loss, and with an additional period or two of asymmetric information, you should find that the premiums asked by all sellers will be equal or close to $\$ 70$. Regardless of whether you continue for additional periods, the game has reproduced the classic case of adverse selection, that is, the process of "bad risks chasing good risks" out of the market (Phelps, 2004, p. 234). Specifically, at asking premiums above $\$ 50$ and less than or equal to $\$ 90$, only high risk type 2 buyers will value insurance enough to purchase it, and low risk type 1 buyers are better off not purchasing (full) insurance.

\section{Part 2: An Insurance Market with Two Types of Buyers and Two Types of Policies}

This part of the game incorporates a common practice by employers who offer health insurance to their workers, or government programs that offer a range of benefits packages (such as in the new Medicare prescription drug benefit). In these settings, individual buyers are often offered a choice over multiple insurance plans. While this practice has several advantages, such as promoting competition, it can also result in several inefficiencies associated with adverse 
selection, as described in detail by Cutler and Zeckhauser (1997). One common result is that high risk individuals may differentially select generous plans (for example, plans that allow greater access to or choice of providers) while low risks select more moderate plans. When this happens because insurers are unable to vary premiums by buyer type, this adverse selection can lead to an inefficient allocation of buyers across plans, with too few buyers opting for generous plans. The second part of this game incorporates multiple plans into the market to again illustrate how adverse selection can lead low risks to forego insurance; further, this part introduces additional government regulations to show how adverse selection can lead to an inefficient sorting of buyers across plans. The discussion of the results can be used to introduce topics like employer subsidies for insurance, adverse selection "death spirals," and practices such as risk adjustment across plans.

Begin this part of the game by providing the students with Part 2 seller and buyer instruction sheets, and give each group a Part 2 record sheet. Read aloud the common portion of the instructions ("Introduction" and "Decisions"), and pause during the "Earnings" section for the students to read privately. As in Part 1, do not reveal the private seller cost and buyer value information to the group. The costs and values vary according to the type of buyer and the type of plan purchased, as shown in Table 3. Following the simple hypothetical example from Cutler and Zeckhauser (1997), the generous plan costs more than the moderate plan for buyers of both types, and the marginal cost of generous insurance relative to moderate is greater for type 2 buyers than type 1 buyers. Buyers of insurance value the generous plan more than the moderate plan, and the benefit difference is greater for type 2 buyers. 
Table 3. Seller Costs and Buyer Values in Part 2

\begin{tabular}{|c|l|l|}
\hline & Type 1 Buyer & Type 2 Buyer \\
\hline Seller Costs & & \\
\hline Moderate Plan Cost & $\$ 40$ & $\$ 70$ \\
\hline Generous Plan Cost & $\$ 60$ & $\$ 100$ \\
\hline Buyer Values & & \\
\hline Moderate Plan Value & $\$ 50$ & $\$ 70$ \\
\hline Generous Plan Value & $\$ 65$ & $\$ 110$ \\
\hline
\end{tabular}

\section{Full Information Periods}

As in the first part of the game, begin with several periods of full information; here this will allow students to observe the efficient sorting of buyers to plans. In the first period, have each seller start by choosing four premiums for policies to be offered to buyers (a moderate plan premium for each type of buyer, and a generous plan premium for each type of buyer). Similar to the first part of the game, sellers do not choose quantity and can sell a maximum of two policies of any kind. While sellers are choosing these premiums, randomly distribute index cards assigning either type 1 or type 2 to the buyers. When all sellers have decided the four premiums for the first period, collect the seller record sheets and post the values on the board or a transparency in a chart. Table 4 gives an example of how to organize the data, along with sample results from this part of the game.

After returning record sheets to sellers, allow buyers to choose to purchase a policy or not; if the buyer elects to purchase, have the buyer indicate the particular seller and plan (generous or moderate), as well as buyer type. Earnings will be calculated as the difference between the premium and the seller cost or buyer value, using the buyer and plan type. 
Table 4. Sample Results from Part 2, by Period

\begin{tabular}{|c|c|c|c|c|c|c|}
\hline \multirow[t]{2}{*}{ Period } & \multicolumn{2}{|c|}{ Seller A } & \multicolumn{2}{|c|}{ Seller B } & \multicolumn{2}{|c|}{ Seller C } \\
\hline & Generous & Moderate & Generous & Moderate & Generous & Moderate \\
\hline $\begin{array}{l}1: \\
\text { Full } \\
\text { Information }\end{array}$ & $\begin{array}{l}\text { T1:\$64.99 } \\
\text { T2:\$107.99 } \\
\text { Sold 1 }\end{array}$ & $\begin{array}{l}\mathrm{T} 1: \$ 46.99 \\
\text { Sold } 1 \\
\mathrm{~T} 2: \$ 75.99\end{array}$ & $\mathrm{~T} 2: \$ 108.50$ & $\begin{array}{l}\mathrm{T} 1: \$ 47 \\
\mathrm{~T} 2: \$ 77\end{array}$ & $\begin{array}{l}\mathrm{T} 1: \$ 72 \\
\mathrm{~T} 2: \$ 108\end{array}$ & $\begin{array}{l}\mathrm{T} 1: \$ 44.95 \\
\text { Sold } 1 \\
\mathrm{~T} 2: \$ 74.95 \\
\text { Sold } 1\end{array}$ \\
\hline $\begin{array}{l}2: \\
\text { Full } \\
\text { Information }\end{array}$ & $\begin{array}{l}\text { T1:\$66.95 } \\
\text { T2:\$106.95 }\end{array}$ & $\begin{array}{l}\text { T1: } \$ 46.99 \\
\text { T2: } \$ 76.99\end{array}$ & $\begin{array}{l}\text { T1:\$68 } \\
\text { T2:\$106 } \\
\text { Sold 2 }\end{array}$ & $\begin{array}{l}\mathrm{T} 1: \$ 45 \\
\mathrm{~T} 2: \$ 74\end{array}$ & $\begin{array}{l}\mathrm{T} 1: \$ 64 \\
\mathrm{~T} 2: \$ 106.50\end{array}$ & $\begin{array}{l}\mathrm{T} 1: \$ 44.95 \\
\text { Sold } 2 \\
\mathrm{~T} 2: \$ 74.95\end{array}$ \\
\hline $\begin{array}{l}\text { 3: } \\
\text { Full } \\
\text { Information }\end{array}$ & $\begin{array}{l}\text { T1:\$64 } \\
\text { T2:\$106 } \\
\text { Sold } 1 \\
\end{array}$ & $\begin{array}{l}\mathrm{T} 1: \$ 44 \\
\text { Sold } 1 \\
\mathrm{~T} 2: \$ 76\end{array}$ & $\begin{array}{l}\text { T1:\$63 } \\
\text { T2:\$104 } \\
\text { Sold } 1 \\
\end{array}$ & $\begin{array}{l}\mathrm{T} 1: \$ 43 \\
\text { Sold } 1 \\
\text { T2:\$73 }\end{array}$ & $\begin{array}{l}\text { T1:\$64 } \\
\text { T2:\$105.49 }\end{array}$ & $\begin{array}{l}\mathrm{T} 1: \$ 44.49 \\
\mathrm{~T} 2: \$ 74.95\end{array}$ \\
\hline $\begin{array}{l}4: \\
\text { Full } \\
\text { Information }\end{array}$ & $\begin{array}{l}\mathrm{T} 1: \$ 63.50 \\
\mathrm{~T} 2: \$ 105\end{array}$ & $\mathrm{~T} 2: \$ 72.99$ & $\begin{array}{l}\text { T2:\$102.47 } \\
\text { Sold } 2\end{array}$ & $\mathrm{~T} 1: \$ 42.47$ & $\begin{array}{l}\mathrm{T} 1: \$ 61.99 \\
\mathrm{~T} 2: \$ 103.87\end{array}$ & $\begin{array}{l}\mathrm{T} 1: \$ 41.99 \\
\text { Sold } 2 \\
\mathrm{~T} 2: \$ 71.99\end{array}$ \\
\hline $\begin{array}{l}5: \\
\text { Asymmetric } \\
\text { Information } \\
\text { (community } \\
\text { rating \& } \\
\text { limits on } \\
\text { premium } \\
\text { increases) }\end{array}$ & $\$ 99$ & $\begin{array}{l}\$ 45 \\
\frac{\text { Sold } 1 \text { to a }}{\text { Type } 1} \\
\frac{\text { Sold } 1 \text { to a }}{\text { Type } 2}\end{array}$ & $\$ 100.01$ & $\$ 46.18$ & $\$ 101.53$ & $\begin{array}{l}\$ 45.99 \\
\frac{\text { Sold } 1 \text { to a }}{\text { Type } 1} \\
\frac{\text { Sold } 1 \text { to a }}{\text { Type 2 }}\end{array}$ \\
\hline $\begin{array}{l}6: \\
\text { Asymmetric } \\
\text { Information } \\
\text { (community } \\
\text { rating only) }\end{array}$ & $\$ 100.01$ & $\$ 70.01$ & $\begin{array}{l}\$ 100.01 \\
\frac{\text { Sold } 2 \text { to }}{\text { Type } 2} \\
\underline{\text { buyers }}\end{array}$ & $\$ 70.01$ & $\$ 100.01$ & $\$ 70.01$ \\
\hline
\end{tabular}

Notes: This table reports the results from an Experimental Economics class in Spring 2005. Each cell shows premiums requested by sellers in periods of the classroom game. In the full information periods, T1 and T2 designate premiums for Type 1 and Type 2 buyers respectively. 
After several full information periods in a competitive group of students, you should observe the premiums of policies sold to be at or near the cost of insurance to sellers, and the efficient sorting of buyers by type of plan to emerge. ${ }^{3}$ Specifically, type 1 buyers will purchase moderate plans since the marginal cost of generous insurance outweighs the marginal benefit $(\$ 20>\$ 15)$. Type 2 buyers will purchase generous plans since the marginal benefit of a generous plan to them exceeds its marginal cost $(\$ 40>\$ 30)$. Moderate plan premiums should be close or equal to $\$ 40$ and generous plan premiums should be close or equal to $\$ 100$. In Table 4 , for example, moderate plans sold in period 4 to type 1 buyers for $\$ 41.99$, while generous plans sold to type 2 buyers for $\$ 102.47$.

\section{Asymmetric Information Periods}

After a period in which you observe the efficient sorting of buyers to plans and selling premiums at or near seller costs, announce that a change will be implemented. Specifically, you can read: "The state legislature has again enacted a mandatory community rating regulation, which requires that insurance companies set premiums at the same level for all buyers. Premiums are allowed to vary by type of plan (moderate or generous). The state has also imposed limits on premium increases; that is, generous and moderate plan premiums can be no more than 10\% above their respective amounts for policies sold in the previous period. Premiums set by sellers in this next period are subject to these new regulations, and no seller can refuse a sale at the posted price in light of the buyer's type." Like community rating regulations, limits on annual premium increases are also a common insurance market reform; for

3 Repetition helps players see the consequences of mistakes, such as one type 2 buyer's decision to buy moderate insurance at a premium above its value as shown in Table 4, period 1. 
example, 31 states applied similar limits to small group markets in the 1990s (Oliver 1999).

Instead of deciding four different premiums that differ by plan type and buyer type, sellers will now announce one premium for a generous plan, and one premium for a moderate plan. While sellers determine the two premiums, once again shuffle and redistribute the index cards assigning buyer type. Then, post sellers' asking premiums on the board; there will be six values (for three sellers, each offering two plans). Finally, allow buyers the option to purchase a policy or not. Buyers will state the type of plan they wish to purchase and from which seller, and will reveal their buyer type. Earnings will be calculated as the difference between premium and seller cost or buyer value, using the buyer and plan type.

The likely effect of these two regulations together is that insurance policies will be sold at premiums around $\$ 44$ for a moderate plan and around $\$ 110$ for a generous plan. When premiums are near this level, all buyers (both high and low risk) will be better off purchasing moderate plans. The high risks benefit by mixing in with the low risks. The period 5 results shown in Table 4 illustrate this outcome.

Once this result has been achieved, you can drop the restriction on premium increases, but keep the community rating rule in effect. You will likely see that sellers increase the premiums of both the moderate and generous plans to a level greater than or equal to the cost of insuring a high risk buyer. This outcome is shown in the period 6 results in Table 4, where all sellers set premiums at one cent above type 2 costs of insurance. When this occurs, expect that type 2 buyers will purchase generous plans, and type 1 buyers will go without insurance. The part 2 results illustrate again how asymmetric information leads to adverse selection, with the bad risks driving the good risks out of the market. 


\section{Suggested Topics for Class Discussion}

This game is a useful way to introduce undergraduate students to the concept of adverse selection and the types of inefficiencies caused by asymmetric information in health insurance markets. When the game is played after a few class periods of instruction on the supply of and demand for health insurance, students should have an understanding of why buyers value insurance, and why insurance premiums vary with buyer type and the level of benefits. In discussing the game's results, you can explicitly state that type corresponds to buyer risk, and describe how community rating mandates in each part of the game lead to asymmetric information about buyer risk level, with buyers knowing their risk level but sellers being unable to use that information to determine premiums. Below I list some specific questions that can be asked of students to stimulate discussion of the game's consequences.

\section{Discussion of Part 1 Results}

What happened to sellers' earnings over the first few periods of the game, and why?

Sellers will describe how their earnings likely decreased from the first period of the game and may even have reached zero; this resulted from the competition among the three sellers as they attempted to attract buyers.

How were sellers affected by the community rating regulation, and did sellers adopt a specific strategy under this regime? Sellers who based premiums on the average cost of the buyer types can give some examples of the losses they incurred if they sold to high risk buyers. Some may describe how such losses then led them to revise their asking premiums upward in a subsequent round.

How were the earnings of type 1 (low risk) and type 2 (high risk) buyers each affected by 
the community rating regulation? If sellers based premiums on the average cost of insuring the type 1 and 2 buyers, then type 2 buyers realized a sizeable increase in their earnings. Whether sellers used an average, or set premiums based on type 2 costs, type 1 buyers were better off not purchasing insurance. As a result, they missed an opportunity to contribute to their earnings. At this point, you can make the connection between buyer earnings and the concept of consumer surplus, and turn the discussion to the efficiency consequences of adverse selection. Type 1 buyers can be asked to calculate the value of lost consumer surplus by providing examples of what their earnings were in the periods prior to the government regulation. You can remind students of the value risk averse individuals receive from insuring against losses, and note that because they were not offered fair premiums and did not buy insurance, type 1 buyers were exposed to risk and made worse off.

Suppose that circumstances other than government regulation make it difficult for sellers to set premiums according to the risk level of the buyers; for example, suppose high risk buyers try to claim they are low risk on insurance applications. Can you think of practices that sellers could adopt to deal with this? Can you think of something that low risk buyers could do to ensure getting lower premiums for insurance? Here you can introduce real and proposed insurance company practices such as experience rating, physical examination requirements, and genetic testing, and you can discuss the willingness of low risk consumers to accept higher deductibles and co-pays in exchange for lower premiums. You can incorporate other market responses to adverse selection, such as those discussed in chapters on asymmetric information published in intermediate microeconomics texts (e.g., Katz and Rosen 1998). 


\section{Discussion of Part 2 Results}

In the initial periods of this part of the game, how did each buyer choose which type of policy to purchase? At this point, you can reveal the cost and value data to all students, and show that at equilibrium premiums, type 2 buyers will always have greater earnings from generous insurance and type 1 buyers from moderate insurance. This represents the efficient sorting of buyers to plans.

When community rating was in effect and limits on premium increases were lifted, what strategy did sellers adopt in determining premiums when buyer type was not known? If sellers use an average cost approach to setting premiums, then type 1 (low risk) buyers will be better off not purchasing insurance, while type 2 buyers will buy generous plans resulting in seller losses. Alternatively, a market with astute sellers may immediately reach an equilibrium in which type 2 buyers purchase generous insurance at or near premiums of $\$ 100$ and low risks continue to forego insurance purchase, as was the case in period 6 of Table 4.

When both regulations (community rating and limits on premium increases) were in effect, why did high risk buyers switch to the moderate plan? A high risk buyer can explain how purchasing moderate insurance at the relatively low premium resulted in much larger earnings. You can then describe how the incentive of facing lower premiums actually does lead some high risk buyers to leave generous plans in favor of moderate plans, and that part of the reason moderate plans cost less is that low risk buyers differentially select them and insurers cannot use or do not have information on risk level. In the real world, where buyer risk level varies across a wide distribution, plan switching is done first by the marginally high risk buyers; this raises the average risk level of the remaining buyers in the generous plan and causes generous plan 
premiums to increase in subsequent periods. Over time, the resulting upward spiral in premiums is said to produce situations where generous plans are no longer offered in the workplace (socalled adverse selection "death spirals). You might also provide case study evidence of actual death spirals and plan switching behavior from Cutler and Reber (1998) and Buchmueller and Feldstein (1997).

What might have happened to insurance premiums if additional periods were played under both regulations? As a result of losses, sellers would likely have increased premiums gradually as allowed by law. A likely result over subsequent periods is that premiums would approach the cost of insuring type 2 buyers in the plans, with moderate insurance premiums high enough that low risks again would have chosen not to buy insurance, at a loss of consumer surplus to them.

What kinds of incentives might be provided so that low risk individuals continue to purchase insurance, and purchase generous plans in particular, in the presence of asymmetric information? Here you can introduce the use of employer subsidies and the favorable tax treatment of insurance which reduce the premium paid by the consumer and may in turn keep low risks in the market. Subsidies in the form of employer contributions are also a way to encourage low risks to choose the generous plan. The discussion can then turn to the types of subsidies used in the workplace, such as fixed dollar contributions (when employers contribute the same dollar amount to premiums of both generous and moderate plans) and proportional subsidies (when employers contribute the same percentage amount to premiums of both generous and moderate plans). You can use material from Cutler and Zeckhauser (1997) to show how the 
latter are more effective at dealing with the effect of adverse selection on plan selection, and to describe other strategies that deter adverse selection, such as retrospective risk adjustment.

At this point, the discussion has introduced many "real world" components regarding the offer of health insurance in the workplace and in government programs, including choice over plans, variation among buyers, the use of employer subsidies for insurance, and the use of proportional subsidies as in the new Medicare prescription drug benefit. For more information on the real world forms and consequences of the insurance market regulations introduced in the game, you can draw on a study by Swartz and Garnick (2000) which tells the story of a community rating mandate in one state's individual insurance market. Simon (2004) provides a brief review of the literature on state small group reforms and their effects, and also estimates an empirical model that may be of interest to students with econometric training. Both of these papers provide more real world evidence that low risk individuals are less likely to have health insurance coverage under regulations that worsen adverse selection. 


\section{References}

Buchmueller, Thomas C. and Paul J. Feldstein. 1997. "The Effect of Price Switching Among Health Plans." Journal of Health Economics, 16(2): 231-247.

Cutler, David J. and Zeckhauser, Richard M. 1997. “Adverse Selection in Health Insurance.” In Frontiers in Health Policy Research, Volume 1, ed. Alan Garber. Cambridge, Massachusetts: The MIT Press, 1-31.

Cutler, David J, and Sarah Reber. 1998. "Paying for Health Insurance: The Tradeoff Between Competition and Adverse Selection." Quarterly Journal of Economics, 113(2): 433-466.

Holt, Charles A. and Sherman, Roger. 1999. "Classroom Games: A Market for Lemons." Journal of Economic Perspectives, 13(1): 204-215.

Kaiser Family Foundation. 2004. "Managed Care and Health Insurance" accessed at www.statefacts.kff.org, published December 23, 2004 and accessed March 8, 2005.

Katz, Michael L., and Harvey S. Rosen. 1998. Microeconomics, Third Edition. Boston, Massachusetts: Irwin McGraw-Hill.

Oliver, Thomas R. 1999. "The Dilemmas of Incrementalism: Logical and Political Constraints in the Design of Health Insurance Reforms." The Journal of Policy Analysis and Management, 18(4): 652-683.

Phelps, Charles A. 2003. Health Economics, Third Edition. Boston, Massachusetts: Addison Wesley.

Simon, Kosali Ilayperuma. 2004. “Adverse Selection in Health Insurance Markets? Evidence from State Small-Group Health Insurance Reforms." Forthcoming in the Journal of Public Economics.

Swartz, Katherine and Deborah W. Garnick. 2000. "Lessons from New Jersey." Journal of Health Politics, Policy and Law, 25(1): 45-70. 


\section{APPENDIX}

\section{Instructions for Sellers}

Seller ID

\section{PART 1.}

Introduction: This is a market of buyers and sellers of insurance policies. The sellers will begin by choosing premiums for their policies. I will collect these decisions and write them on the blackboard, then I will give buyers the chance to purchase a policy from one of the sellers. There will be two types of buyers, type 1 and type 2 . Policies sold to type 2 buyers cost more to the sellers, but are worth more to the buyers.

Earnings (students should read privately): Sellers earn money by selling one or two policies at premiums above cost. The cost associated with a policy sold to each buyer type is shown below:

\begin{tabular}{|l|c|}
\hline & Seller cost of one policy \\
\hline Sold to a type 1 buyer & $\$ 40$ \\
\hline Sold to a type 2 buyer & $\$ 70$ \\
\hline
\end{tabular}

Seller earnings in a given period are calculated as the premiums received for the policy or policies sold, minus the costs of the policy or policies sold according to the buyer type(s). This calculation is shown on your record sheet. Sellers can not refuse a sale at a posted premium, and can sell no more than two policies; a seller who does not make a sale in a period will earn $\$ 0$.

Decisions: In each period, sellers will decide premiums and will record this information on their record sheets. I will then collect the record sheets, post the premiums on the board next to the seller ID, and draw cards to randomly determine which buyers are type 1 and which are type 2 . Buyers will then have the chance to purchase one policy from one of the sellers; buyers may also choose not to purchase a policy altogether. This process will be repeated for several periods, in which buyer types will be re-assigned and new buyers will be given the chance to make the first purchase. Are there any questions? 
PART 1.

Record Keeping: Use the table below to record your decisions and to calculate (hypothetical) earnings.

\begin{tabular}{|c|c|c|c|c|c|c|}
\hline & Period 1 & Period 2 & Period 3 & Period 4 & Period 5 & Period 6 \\
\hline $\begin{array}{l}\text { 1) asking premium for policy sold to } \\
\text { type } 1 \text { buyer (a.k.a. "type } 1 \text { policy") }\end{array}$ & & & & & & \\
\hline $\begin{array}{l}\text { 2) asking premium for policy sold to } \\
\text { type } 2 \text { buyer (a.k.a. "type } 2 \text { policy") }\end{array}$ & & & & & & \\
\hline 3) premium received for first policy sold & & & & & & \\
\hline $\begin{array}{l}\text { 4) cost of first policy sold, from } \\
\text { instructions }\end{array}$ & & & & & & \\
\hline 5) earnings on first policy sold: (3)-(4) & & & & & & \\
\hline $\begin{array}{l}\text { 6) premium received for second policy } \\
\text { sold }\end{array}$ & & & & & & \\
\hline $\begin{array}{l}\text { 7) cost of second policy sold, from } \\
\text { instructions }\end{array}$ & & & & & & \\
\hline 8) earnings on second policy sold:(6)-(7) & & & & & & \\
\hline 9) total earnings $(5)+(8)$ & & & & & & \\
\hline 10) cumulative earnings over all periods & & & & & & \\
\hline
\end{tabular}


Instructions for Buyers

Buyer ID

PART 1.

Introduction: This is a market of buyers and sellers of insurance policies. The sellers will begin by choosing premiums for their policies. I will collect these decisions and write them on the blackboard, then I will give buyers the chance to purchase a policy from one of the sellers. There will be two types of buyers, type 1 and type 2 . Policies sold to type 2 buyers cost more to the sellers, but are worth more to the buyers.

Earnings (students should read privately): Buyers earn money by purchasing a policy at a premium that is less than the monetary value they place on the policy. The monetary value associated with a policy for each buyer type is shown below:

\begin{tabular}{|l|c|}
\hline & Buyer value of one policy \\
\hline Purchased by a type 1 buyer & $\$ 50$ \\
\hline Purchased by a type 2 buyer & $\$ 90$ \\
\hline
\end{tabular}

Buyer earnings in a given period are calculated as the monetary value of the policy, according to the buyer's type, minus the premium paid. This calculation is shown on your record sheet. Buyers can purchase one policy or no policy; a buyer who does not make a purchase in a period will earn $\$ 0$.

Decisions: In each period, sellers will decide premiums and will record this information on their record sheets. I will then collect the record sheets, post the premiums on the board next to the seller ID, and draw cards to randomly determine which buyers are type 1 and which are type 2 . Buyers will then have the chance to purchase one policy from one of the sellers; buyers may also choose not to purchase a policy altogether. This process will be repeated for several periods, in which buyer types will be re-assigned and new buyers will be given the chance to make the first purchase. Are there any questions? 
Record Keeping: Use the table below to record your decisions and to calculate (hypothetical) earnings.

\begin{tabular}{|l|l|l|l|l|l|l|}
\hline & Period 1 & Period 2 & Period 3 & Period 4 & Period 5 & Period 6 \\
\hline 1) your type this period & & & & & & \\
\hline $\begin{array}{l}\text { 2) ID of seller you purchased } \\
\text { from }\end{array}$ & & & & & & \\
\hline 3) premium paid to seller & & & & & & \\
\hline $\begin{array}{l}\text { 4) value of policy to you, } \\
\text { according to your type (from } \\
\text { instructions) }\end{array}$ & & & & & & \\
\hline 5) earnings: (4) - (3) & & & & & & \\
\hline $\begin{array}{l}\text { 6) cumulative earnings over all } \\
\text { periods }\end{array}$ & & & & & & \\
\hline
\end{tabular}




\section{PART 2.}

Introduction: In this part of the game, buyers and sellers can exchange two types of insurance products: a plan with generous coverage, and a plan with moderate coverage. The generous plan offers additional benefits and privileges over the moderate plan; as a result the generous plan is worth more to buyers but costs more to sellers. Sellers will begin by choosing premiums for their policies by buyer and plan type; buyers will then have a chance to purchase a policy from one of the sellers at posted premiums.

Earnings (students should read privately): Sellers earn money by selling one or two policies at premiums above cost. The cost associated with each policy for each buyer type is shown below:

\begin{tabular}{|l|c|c|}
\hline & Seller Cost of a Generous Plan & Seller Cost of a Moderate Plan \\
\hline Sold to a Type 1 Buyer & $\$ 60$ & $\$ 40$ \\
\hline Sold to a Type 2 Buyer & $\$ 100$ & $\$ 70$ \\
\hline
\end{tabular}

Seller earnings in a given period are calculated as the premiums received for the policy or policies sold, minus the cost of the policy or policies sold according to buyer and policy type(s). This calculation is shown on your record sheet. Sellers can not refuse a sale at a posted premium, and can sell no more than two policies; a seller who does not make a sale in a period will earn $\$ 0$.

Decisions: In the first period, each seller will determine four separate premiums (generous plan premiums for each buyer type, and moderate plan premiums for each buyer type). Sellers will record this information on their record sheets. I will then collect the record sheets, post premiums on the board next to the seller ID, and draw cards to randomly determine buyer type. Buyers will have the chance to purchase one policy from a seller; buyers may also choose not to purchase altogether. This process will be repeated for several periods, in which buyer types will be reassigned and new buyers will be given the chance to make the first purchase. Are there any questions? 


\section{PART 2.}

Record Keeping: Use the table below to record your decisions and to calculate your (hypothetical) earnings.

\begin{tabular}{|c|c|c|c|c|c|c|}
\hline & Period 1 & Period 2 & Period 3 & Period 4 & Period 5 & Period 6 \\
\hline \multicolumn{7}{|c|}{$\begin{array}{l}\text { 1) asking premium for Generous Plan, Type } \\
1 \text { buyer }\end{array}$} \\
\hline \multicolumn{7}{|c|}{$\begin{array}{l}\text { 2) asking premium for Generous Plan, Type } \\
2 \text { buyer }\end{array}$} \\
\hline \multicolumn{7}{|c|}{$\begin{array}{l}\text { 3) asking premium for Moderate Plan, Type } \\
1 \text { buyer }\end{array}$} \\
\hline \multicolumn{7}{|c|}{$\begin{array}{l}\text { 4) asking premium for Moderate Plan, Type } \\
2 \text { buyer }\end{array}$} \\
\hline \multicolumn{7}{|l|}{ 5) premium received for first policy sold } \\
\hline \multicolumn{7}{|l|}{ 6) type of buyer who purchased } \\
\hline \multicolumn{7}{|c|}{$\begin{array}{l}\text { 7) cost of first policy sold, for plan type and } \\
\text { buyer type in (6), from instructions }\end{array}$} \\
\hline \multicolumn{7}{|l|}{ 8) earnings on first policy sold: (5)-(7) } \\
\hline \multicolumn{7}{|c|}{ 9) premium received for second policy sold } \\
\hline \multicolumn{7}{|l|}{ 10) type of buyer who purchased } \\
\hline \multicolumn{7}{|c|}{$\begin{array}{l}\text { 11) cost of second policy sold, for plan type } \\
\text { and buyer type in (10), from instructions }\end{array}$} \\
\hline \multicolumn{7}{|c|}{ 12) earnings on second policy sold:(9)-(11) } \\
\hline \multicolumn{7}{|l|}{ 13) total earnings: $(8)+(12)$} \\
\hline 14) cumulative earnings in all periods & & & & & & \\
\hline
\end{tabular}


PART 2.

Introduction: In this part of the game, buyers and sellers can exchange two types of insurance products: a plan with generous coverage, and a plan with moderate coverage. The generous plan offers additional benefits and privileges over the moderate plan; as a result the generous plan is worth more to buyers but costs more to sellers. Sellers will begin by choosing premiums for their policies by buyer and plan type; buyers will then have a chance to purchase a policy from one of the sellers at posted premiums.

Earnings (students should read privately): Buyers earn money by purchasing a policy at a premium that is less than the monetary value they place on the policy. The monetary value associated with both policies for each buyer type is shown below:

\begin{tabular}{|l|c|c|}
\hline & Buyer Value of a Generous Plan & Buyer Value of a Moderate Plan \\
\hline Purchased by a Type 1 Buyer & $\$ 65$ & $\$ 50$ \\
\hline Purchased by a Type 2 Buyer & $\$ 110$ & $\$ 70$ \\
\hline
\end{tabular}

Buyer earnings in a given period are calculated as the monetary value of the policy, according to the type of policy and type of buyer, minus the premium paid. This calculation is shown on your record sheet. Buyers can purchase one policy or no policy; a buyer who does not make a purchase in a period will earn $\$ 0$.

Decisions: In the first period, each seller will determine four separate premiums (generous plan premiums for each buyer type, and moderate plan premiums for each buyer type). Sellers will record this information on their record sheets. I will then collect the record sheets, post premiums on the board next to the seller ID, and draw cards to randomly determine buyer type. Buyers will have the chance to purchase one policy from a seller; buyers may also choose not to purchase altogether. This process will be repeated for several periods, in which buyer types will be reassigned and new buyers will be given the chance to make the first purchase. Are there any questions? 


\section{PART 2.}

Record Keeping: Use the table below to record your decisions and to calculate your (hypothetical) earnings.

\begin{tabular}{|c|c|c|c|c|c|c|}
\hline & Period 1 & Period 2 & Period 3 & Period 4 & Period 5 & Period 6 \\
\hline \multicolumn{7}{|l|}{ 1) your type this period: 1 or 2} \\
\hline \multicolumn{7}{|l|}{$\begin{array}{l}\text { 2) type of plan purchased: generous } \\
(\mathrm{G}) \text { or moderate }(\mathrm{M})\end{array}$} \\
\hline \multicolumn{7}{|l|}{ 3) ID of seller you purchased from } \\
\hline \multicolumn{7}{|l|}{ 4) premium paid to seller } \\
\hline \multicolumn{7}{|l|}{$\begin{array}{l}\text { 5) value of policy to you, by your type } \\
\text { and by type of policy (from } \\
\text { instructions) }\end{array}$} \\
\hline \multicolumn{7}{|l|}{ 6) earnings: (5) - (4) } \\
\hline 7) cumulative earnings over all periods & & & & & & \\
\hline
\end{tabular}

